\title{
Donald Trump's Vocabulary Selection Strategy in a Public Speech for the First Time Since Covid-19 Diagnosis
}

\author{
Arini Hidayah $^{1 *}$ and Widyashanti Kunthara Anindhita ${ }^{2}$ \\ ${ }^{12}$ Surakarta University, Surakarta, Indonesia \\ "Corresponding author. Email: ariniunsa@gmail.com; wk.anindita@gmail.com
}

\begin{abstract}
This study applied a critical discourse analysis approach to Donald Trump's speech at his first public event since being diagnosed with Covid-19. The objective of this research is to describe the vocabulary selection strategy used by Donald Trump in his first public speech since being diagnosed with Covid-19. This study is a descriptive qualitative study. Documentation is a data collection technique. The research data came from Donald Trump's speech at the first public event since Covid-19 was diagnosed on October 10, 2020. This study found three types of vocabulary for classifying, four types of vocabulary for limiting views, three types of vocabulary for discourse battle, and three types of vocabulary for marginalization.
\end{abstract}

Keywords: critical discourse analysis, speech, and vocabulary

\section{INTRODUCTION}

Politics is a struggle for power with the goal of putting specific political, economic, and social ideas into action. Language is crucial in this process because it prepares, accompanies, influences, and plays a role in every political action. [1]-[3]. According to the philosophy expressed in many myths and religions, language is the source of human life and power. [4], [5]. Words are critical linguistic units in language because human language is composed of a series of words or groups of words. Language is critical to human life because it enables individuals to communicate with one another and allows humans to express their thoughts, ideas, and feelings through language [6], [7]. Widdowson \& Kramsch (2000) state that Language is the major medium via which we conduct our social lives. When utilized in communicative contexts, it is intricately related to culture in a variety of ways. To begin, the words expressed by individuals connect to shared experiences. They communicate communicable facts, ideas, or events by referring to a shared body of knowledge about the world. Furthermore, words represent their writers' attitudes and beliefs, as well as their point of view, which is shared by others. Language, in both circumstances, represents cultural reality. Language is a system of communication that consists of a collection of sounds and written symbols that the inhabitants of a specific country or region use when speaking or writing.
Discourse analysis is sometimes defined as a subfield of linguistics, or the scientific study of language. Furthermore, discourse analysts investigate how sentences and utterances work together to produce texts and interactions, as well as how those texts and interactions fit into our social context. [7], [9]-[11]. Discourse analysis is the study of how members of a speech community use language. Thus, discourse analysis [12] is concerned with the examination of language use. An approach of research known as discourse analysis examines how written or spoken language interacts with its social setting. Its goal is to provide students a better grasp of how language is utilized in real life.

The study of ideology requires a discourse-analytic approach. It is crucial to look at ideology from a discourse analytical perspective since people acquire, communicate and reproduce their beliefs primarily through text and speech [2], [13], [14]. Dunmire (2012) states that language politics and language ideology research seeks to discover and critique "any set of views about language expressed by users as a rationalization or justification for observed language structure and use." Language ideologies play a crucial role in the creation and implementation of official and standard languages policies, language planning, language academies, and language education programs. Language ideology is an important yet underappreciated phenomena that connects social structure and modalities of communication. A system of beliefs and ideals held by a 
group or individual is referred to as ideology [16]-[18]. In both cases, this implies that specific discourse structures may be necessary for the effective expression or persuasive communication of ideological meanings. The relationship between discourse and ideology [13], [19] is examined through discourse structure, which includes lexical deviations, material, syntactic structures such as active-passive sentences, pronominals and how we use them, metaphors, arguments, implications, and a variety of other discourse components. Political discourse is determined not only by its term structure but also by its political context, such as Trump's speech.

Linguistic critics view language as a social practice, through which a group establishes and propagates its ideology. Critical linguistics is mainly developed from linguistic theory. Research conducted by Fowler et al via Eriyanto (2011) is to see how certain grammars and certain vocabulary choices carry certain implications and ideologies. Fowler et al [20] in building their analytical model based on Halliday's description of language structure and function. In building his analytical model, Fowler based on Halliday's description of language structure and function. The purpose and structure of language serve as the foundation for the grammatical framework, which offers the tools for communicating with the audience. Fowler uses the language and practice of its usage to define ideological practice.

According to Fowler via [20] sees language as a classification system. Language defines how people see the world, allowing them to manage and regulate their social reality experience. However, this classification system varies from one person or group to another because different groups have different cultural, social, and political experiences. Fowler observes how language used to depict social problems may reveal various experiences and politics. From Fowler's thoughts, Eriyanto (2011) divides the language classification system through four vocabulary selection strategies, which are explained as follows:

\subsection{Vocabulary for classifying}

Language basically always provides classification. Certain realities are categorized like this and are finally distinguished from other realities. People classify things because reality is so complicated that they construct simplifications and abstractions from it. This reality can not only be identified, but it is actively attempting to differentiate itself from others. Classification creates a framework for managing information and experiences.

\subsection{Vocabulary for limiting the views}

Language is basically limiting. Classification gives a framework for organizing data and experiences. Vocabulary has an effect on how we comprehend and interpret events. This is because the audience does not experience or follow a certain vocabulary that will be associated with a particular reality.

\subsection{Vocabulary for discourse battle}

Vocabulary must be understood in the context of discourse battles. In a report, each political party has its own perspective or point of view on a subject. Classification gives a framework for organizing data and experiences. They have assertions of truth, reasons, and answers for a situation. They not only have different versions, but they also aim to make the one that is regarded the most correct and decisive in influencing public opinion the most correct and decisive in influencing public opinion. In order to gain public acceptability, each party employs its own terminology and attempts to impose the vocabulary that is more widely accepted by the public.

\subsection{Vocabulary for marginalization}

Fowler's basic argument is that certain linguistic choices carry certain ideological values. The word is seen not as something neutral, but carries certain ideological implications. The usage of words, sentences, structures, particular sentence patterns, and propositions is considered as an expression of ideology rather than a technical matter of grammar or linguistics.: an effort to form public opinion, affirm, and justify one's own party and exclude others. The use of language is seen as not neutral because it carries certain ideological implications. The text produces a "reading position" for the audience, in the sense of providing a perspective on how a text should be read and understood, even though the meaning of a text involves a transactional relationship with the reader.

Dialogue is widely investigated in terms of ideological ideologies, such as lexical aberrations, material and syntactic structures like active-passive phrases, pronominals and our usage of them, metaphors and arguments. The term structure of political speech is important, but so is the political environment in which it is delivered [19]. This research looked at Trump's first public statement after being diagnosed with Covid-19. Due of Donald Trump's apparent command of the English language, his speech is an intriguing object for linguistic analysis. In his remarks, Donald Trump has made an effort to project an image of himself as a leader who is fluent in the English language.Donald Trump's speech is fascinating to study because of his language proficiency. Donald Trump attempted to create an image of himself as a context leader through the vocabulary selection strategy he employed in his speech. This paper aims to describe the vocabulary selection strategy in Donald Trump's speech at a public event for the first time since after Covid-19 diagnosis.

\section{METHOD}

Qualitative research was used to conduct the study. Using a variety of natural approaches, qualitative research seeks to get a descriptive understanding of events experienced by research participants, such as behavior, perception, motivation, and action. Descriptive qualitative research is the process of collecting, describing, classifying, analyzing, and 
drawing conclusions from data [21]-[23].Sukmadinata [24] defines qualitative research as research that aims to depict and analyze a marvel, event, social movement, person, or group thought. In this study, descriptive qualitative research was used to describe the vocabulary selection strategy in For the first time since his Covid19 diagnosis, Donald Trump spoke in front of the public at a sporting event.

Arikunto (2002) defines the source of data as the subject from which all data for a study are derived. According to Siyoto \& Sodik (2015), the source of data refers to the source from which the researcher obtained the data or the source from which the data was taken. It means that data is the object that would be analyzed by the researcher. The data in the research is Donald Trump's speech at his first public event since being diagnosed with Covid-19.

Purposive sampling is used in this study to obtain the source sample. Purposive sampling, as defined by Arikunto (2002) is the process of selecting subjects for a sample without regard for their level or area, but rather for their specific purpose. Purposive sampling is chosen by the researcher because it relies on the researcher's judgment rather than randomization when selecting the object. The researcher chooses the purposive sampling technique can adjust to vocabulary selection strategy in Donald Trump's speech at a public event for the first time since after Covid-19 diagnosis.

The data in this research were collected using a documentary technique. Documentation is a technique used in logical investigation to collect data through the use of documents. The document is entirely composed of written material. This technique is utilized because it is capable of examining and interpreting something [23], [24], [27]. The following steps were taken to collect the data: (1) Conducting an internet search and obtaining a transcript of President Donald Trump's speech at the first event following his Covid-19 diagnosis; (2) Carefully reading and comprehending vocabulary selection strategy through the study of critical discourse analysis theories; (3) Data collection and classification according to vocabulary selection strategy.

The process of arranging and categorizing data into patterns, categories, and fundamental units of description in order to discover a theme and build a working hypothesis based on the data's suggestions is known as data analysis. [9], [27], [28]. Process data by performing the following steps: (1) Look for a transcript of Donald Trump's address at the first public event since the election. Covid-19 identification; (2) Making notes for data that has a relationship with the problem that wants to be analyzed on the notebook or computer; (3) Classifying the data based on vocabulary selection; (4) Analyzing the data based on vocabulary selection; (5) Drawing conclusion.

\section{RESULTS AND DISCUSSION}

The vocabulary selection strategy for the following is President Donald Trump's address at the first public event since the Covid-19 diagnosis on October 10, 2020.:

\subsection{Vocabulary for Classifying}

Language, in general, provides classification. Certain realities are classified as realities and distinguished from others. People classify things because reality is so complex that they build simplifications and abstractions from it. This reality can not only be identified, but it is actively attempting to separate itself from others. Classification creates a framework for managing information and experiences. In his speech at the first public event since being diagnosed with Covid-19, President Donald Trump also offered an overview or reality that was classified into three classification data, which will be discussed further below:

\subsubsection{Vocabulary To Represent Classification of Hope and Planning}

The terminology used to convey the classification of hopes and plans in President Donald Trump's speech at the first public event since his Covid-19 diagnosis discovered two data points, one of which is as follows.:

\section{(B1.1)}

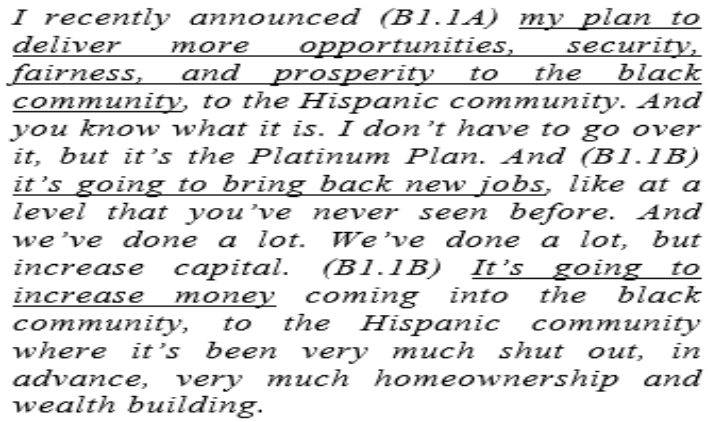

Based on the data above, the vocabulary that shows hope is datum $\mathrm{B} 1.1 \mathrm{~B}$ and datum $\mathrm{B} 1.1 \mathrm{~B}$. The vocabulary that shows planning is datum $\mathrm{B} 1.1 \mathrm{~A}$. The first vocabulary of hope is datum B1.1B shows that Trump hopes that if he is re-elected president again, Trump will provide many new jobs to Black and Hispanic community. The second vocabulary of hope is that datum B1.1B shows that Trump hopes that after giving many new jobs to the Hispanic Community, their income will increase.

The first planning vocabulary is datum B1.1A shows that Trump's plan is to increase the income of the Hispanic Community by providing opportunity, security, justice, and prosperity for the Hispanic community. While the second planning vocabulary, namely platinum plan in datum B1.1, refers to the first planning vocabulary that Trump considers platinum planning.

\subsubsection{Vocabulary To Represent Classification of Achievement and Concern}

Vocabulary to represent the classification of achievement and concern in President Donald Trump's 
address at the first public event since the Covid-19 diagnosis found 1 datum which will be discussed as follows:

\section{(B1.3)}

So (B1.3A) we are now beginning the fastest economic recovery in history. (BI.3B) We created a record 11.4 million jobs just in the last four months. That's the fastest ever. The US has seen the smallest economic contraction of any major nation anywhere in the world. So we've seen the smallest going down. If you look at it, that's an incredible statement. Our opponents will crush the comeback with unscientific lockdowns. (B1.3C) They want to lock everything down. Here we go again. (B1.3D) They want to lock it down. (BI.3E) We're not going to let it happened. (B1.3F) We're not going to let it happen. So important you get out and vote. You got to get out and vote.

Based on datum B1.3 above, the vocabulary which shows achievement is $\mathrm{B} 1.3 \mathrm{~A}$ and $\mathrm{B} 1.3 \mathrm{~B}$. The vocabulary that shows concern is $\mathrm{B} 1.3 \mathrm{C}, \mathrm{B} 1.3 \mathrm{D}$, $\mathrm{B} 1.3 \mathrm{E}$, and B1.3F.

The first achievement vocabulary is B1.3A in datum B1.3 shows that Trump's achievement of economic recovery in America during his tenure as President of America. The second achievement vocabulary is B1.3B in datum B1.3 still tells about the American economy. Trump as President of America has created a record 11.4 million jobs in 4 months.

The first concern vocabulary is $\mathrm{B} 1.3 \mathrm{C}$ in datum B1.3 their vocabulary is focused on Biden and his supporters. Trump's first vocabulary of concern tells that Biden and his supporters will lock up or hinder Trump's efforts to build America's economy. The second and third concern vocabulary is the same, namely, B1.3E and $\mathrm{B} 1.3 \mathrm{~F}$ data. The second concern vocabulary is repeated twice because it is important. Trump will not allow Biden and his supporters to hinder what Trump is doing to increase America's economy

\subsubsection{Vocabulary To Represent Classification of Belief and Spirit}

Vocabulary to represent the classification of belief and spirit in President Donald Trump's address at the first public event since the Covid-19 diagnosis found 1 datum which will be discussed as follows:

$$
\text { (B1.4) }
$$

(B1.4A) We got a great poll in Florida. (B1.4B) Got a great poll in North Carolina. (B1.4C) Got a great poll in Arizona. (B1 4D) Got a great poll in Nevada, actually. (B1.4E) Just got a great poll in Nevpda. I think we're doing really well. I mean, this is in addition to states that we're going to win. Georgia is looking fantastic. Texas is looking for fantastic. Well, think about Texas, they have no oil, they don't want oil. They don't want guns. They don't want religion. (B1.4F) $\underline{I}$ don't think you're going to win Texas very well. (B1.4G) Now, we 've got a great poll in Texas. We're getting great polls all over the place and they understand it. It's driving them crazy. And you know why though? And Candace, it is. (B1.4H) It's because of the spirit. (B1.4I) There's a spirit the likes of which this country hasn't seen in a very, very long time.

Based on datum B1.4 above, the vocabulary that shows belief is B1.4A, B1.4B, B1.4C, B1.4D, B1.4E, $\mathrm{B} 1.4 \mathrm{~F}$ and $\mathrm{B} 1.4 \mathrm{H}$. The vocabulary that shows the spirit is $\mathrm{B} 1.4 \mathrm{H}$ and $\mathrm{B} 1.4 \mathrm{I}$. The first belief vocabulary is $\mathrm{B} 1.4 \mathrm{~A}$, the second belief vocabulary is $\mathrm{B} 1.4 \mathrm{~B}$, the third belief vocabulary is $\mathrm{B} 1.4 \mathrm{C}$, the fourth belief vocabulary is $\mathrm{B} 1.4 \mathrm{D}$, the fifth belief vocabulary is $\mathrm{B} 1.4 \mathrm{E}$, the sixth belief vocabulary is B1.4F. It explains that based on the poll of votes chosen by the President of America, Trump won in several areas such as Florida, North Carolina, Arizona, Nevada, and Texas. The seventh belief vocabulary is B1.4F makes it clear that Trump believes Biden's poll in Texas is low. This explains that Trump believes in the public that based on the poll Trump wins in the US presidential election. The first spirit vocabulary is $\mathrm{B} 1.4 \mathrm{H}$ and the second spirit vocabulary B1.4I in datum B1.4 shows that Trump sees American society as having the enthusiasm to elect Trump to be the next President.

\subsection{Vocabulary for Limiting Views}

Classification creates a framework for managing information and experiences. Because the audience does not encounter or follow a specific vocabulary that will be associated with a particular reality, vocabulary determines how we comprehend and interpret an event. President Donald Trump's statement at the first public event since his Covid-19 diagnosis painted a picture of reality that was limited to numerous points of view.

\subsubsection{Vocabulary To Represent Limitation of The} Presidential Election View

Classification gives a framework for regulating information and experiences. Because the audience does not experience or follow a specific vocabulary that will be associated with a specific reality, vocabulary determines how we comprehend and interpret an event. In his statement at the first public event since being diagnosed with Covid-19, President Donald Trump painted a picture of reality that was limited to certain points of view:

(B2.1) 
Well, thank you very much and keep that enthusiasm going, get out and vote. (B2.1A) We got to vote. (B2.1B) We got to vote these people into oblivion, (B2.1C) vote them into oblivion. Got to get rid of them so bad for our country. First of all, I'm feeling great. I don't know about you. How's everyone feeling? Good? And I'm honored to welcome, we call this a peaceful protest to the White House in support of the incredible men and women of law enforcement and all of the people that work so well with us. I have to tell you our black community, our Hispanic community, thank you very much. Thank you.

The vocabulary limiting views on the presidential election in dataum B2.1 is B2.1A, B21B, and B2.1C Vocabulary we generalize that all American society. The vocabulary that represents the limitation of views on the presidential election, firstly B2.1A, secondly B2.1B, and thirdly B2.1C explain about Trump inviting all Americans to go to vote for the American presidential election.

\subsubsection{Vocabulary To Represent Limitation of Economic View}

The terminology used to convey the limitations of economic perspectives in President Donald Trump's speech at the first public event since his Covid-19 diagnosis discovered two data points, one of which will be discussed below:

\section{(B2.4)}

So (B2.4A) we are now beginning the fastest economic recovery in history. (B2.4B) $\mathrm{We}$ created a record 11.4 million jobs just in the last four months. That's the fastest ever. (B2.4C) The US has seen the smallest economic contraction of any major nation anywhere in the world. So we've seen the smallest going down. If you look at it, that's an incredible statement. Our opponents will crush the comeback with unscientific lockdowns. They want to lock everything down. Here we go again. They want to lock it down. We're not going to let it happened. We're not going to let it happen. So important you get out and vote. You got to get out and vote.

The vocabulary of limiting view on the economy in B2.4 datum is B2.4A, B2.4B, and B2.4C. The vocabulary of limitation of the first economic view, B2.4A, explains that America is the country with the fastest economic recovery. The second economic view limitation vocabulary is $\mathrm{B} 2.4 \mathrm{~B}$ describes America getting a record in a four-month period, 11.4 million jobs were created. The vocabulary of third limitation of the economic outlook, B2.4C, explains that In comparison to other countries, America has had the smallest economic downturn. Trump's purpose in limiting the public's perspective of the economy is to demonstrate that what Trump is doing to advance the American economy is indeed advancing the American economy.

\subsubsection{Vocabulary To Represent Limitation of Peace View}

The word used to convey the limitation of the peace position in President Donald Trump's speech at the first public event following the diagnosis of Covid-19 discovered 2 data points, one of which will be discussed below:

(B2.6A) We're going to build up a peaceful and safer neighborhood program like you haven't seen with the highest standards of policing, we'll create a healthcare system that delivers better care at a lower cost.

The vocabulary of limiting views on peace in data B2.6, namely B2.6A explains that Trump will try to improve security standards in the police in order to create peace in American society. Trump's goal is to limit the view of peace so that people vote for Trump in the presidential election.

\subsubsection{Vocabulary To Represent Limitation of Health View}

Vocabulary to reflect the limits of health view in President Donald Trump's address at the first public event following the diagnosis of Covid-19 discovered 1 data that will be examined more below:

(B2.7)

We're going to build up a peaceful and safer neighborhood program like you haven't seen with the highest standards of policing, (B2.7A) we'll create a healthcare system that delivers better care at a lower cost. $(B 2.7 B)$ We want to get great healthcare. And that's what we're doing. (B2.7C) Great healthcare. And we'll always take care of pre-existing conditions, always. And I think we're at a point where we're getting and right now if you look at what we've done in healthcare, people don't talk about it. We've done an incredible job. (B2.7D) Less expensive healthcare. (B2.7E) Much better healthcare at a much less expensive price. You can't do better than that. And it's happening and it's happening fast.

The vocabulary of limiting views on health in datum $\mathrm{B} 2.7$ is $\mathrm{B} 2.7 \mathrm{~A}, \mathrm{~B} 2.7 \mathrm{~B}, \mathrm{~B} 2.7 \mathrm{C}, \mathrm{B} 2.7 \mathrm{D}$, and $\mathrm{B} 2.7 \mathrm{E}$. The first vocabulary restricting views on health B2.7A. Second, B2.7B, and third, B2.7C. That vocabularies have the same meaning, namely, Trump wants Americans to get good health care. Fourth, B2.7D and fifth B2.7E explain Trump's desire to change the quality of health to better and affordable prices. Trump's goal is to limit views on health so that people vote Trump in the presidential election.

\subsection{Vocabulary For Discourse Battle}

In the framework of discourse battles, vocabulary must be grasped. Each party has its own interpretation 
or point of view on an issue. They have assertions of truth, reasons, and answers for a situation. They not only have different versions, but they also aim to make the one that is regarded the most correct and decisive in influencing public opinion the most correct and decisive in influencing public opinion. In order to gain public acceptability, each party employs its own terminology and attempts to impose the vocabulary that is more widely accepted by the public. President Donald Trump's statement at the first public event since his Covid-19 diagnosis gave an image or reality that clashed with debate about a subject.

\subsubsection{Vocabulary to Represent Covid-19 Discourse Battle}

Vocabulary used to represent the Covid-19 discourse conflict in President Donald Trump's speech at the first public event following the Covid-19 diagnosis identified 1 datum, which will be examined further below:

\section{(B3.1)}

(B3.1A) I want you to know our nation's going to defeat this terrible China virus, as we call it and $(B 3.1 B)$ we're producing powerful therapies and drugs and we're healing the sick and we're going to recover. And (B3.1C) the vaccine is coming out very, very quickly in record time. As you know, it's coming out very, very soon. (B3.1D) We have great, great companies doing it and there'll be distributing it. And we will through our military very, very rapidly, through the power of the American spirit, (B3.lE) I think more than anything else, science medicine will eradicate the China virus once and for all. We'll get rid of it all over the world.

The vocabulary to represent Covid-19 discourse battle in datum B3.1 is B3.1A, B3.1B, B3.1C, B3.1D, and B3.1E. The first vocabulary to represent Covid-19 discourse battle in datum B3.1, B3.1A, explained that Trump explained to the public that America could face Covid-19. The vocabulary of this terrible China virus refers to Covid-19. Second, B3.1B, explaining that America is producing great therapies and drugs so that Americans affected by Covid-19 will recover. The third, B3.1C and the fourth B3.1D are spoken by Trump twice, this indicates that the Covid-19 vaccine is very important because it prevents more people affected by Covid-19. The five, B3.1E have the same meaning, namely America has a good vaccine industry to produce Covid-19 vaccines. Seventh, B3.1F, explaining that Trump thinks that America's drug knowledge will wipe out Covid-19. Trump's goal is to represent the battle against Covid-19 so that people believe that America has a cure, therapy, and vaccine to deal with Covid-19.

\subsubsection{Vocabulary To Represent Black and Latino} American Discourse Battle

Vocabulary to reflect Black and Latino American discourse fight in President Donald Trump's address at the first public event since the diagnosis of Covid-19 discovered three statistics, one of which will be presented below:

(B3.2)

Every day, (B3.2A) more Black and Latino Americans are leaving behind left wing politicians. It's what they are. They failed for many years and many, many decades. Democrats have run nearly every inner city in America and $I$ mean, for 100 years and their policies have delivered nothing but calamity, poverty and trouble.(B3.2B)Sleepy Joe Biden has betrayed black and Latino Americans. If you think he can run this country, you're wrong. For half a century, shipping your jobs to China, that's what they've been doing. We're bringing the jobs back. We've been bringing them back. We've been charging China a lot of money too, with the tariffs, a lot of money, billions and billions of dollars.

Vocabulary to represent Black and Latino American discourse battle in B3.2A and B3.2B . First, B3.2A explaining about left-wing politics have been abandoned by Black and Latino Americans in American culture. (left wing politics in question is Democrats). Second, B3.2B, explaining that Trump thinks because he is a Democrat, Biden of the Democratic Party has forsaken Black and Latino Americans, sent the work of Black and Latino Americans to China. Trump wants to bring Black and Latino Americans jobs back to America. Trump's goal is to make Black and Latino America income increase, so that society vote for Trump in the presidential election.

\subsubsection{Vocabulary To Represent Hispanic Community Discourse Battle}

Vocabulary to depict the fight of Hispanic Community conversation in President Donald Trump's speech at the first public event since the diagnosis of Covid-19 discovered two data points, one of which will be discussed more below:

(B3.6)

(B3.6A)We achieved the lowest black and Hispanic unemployment rate in the history of our country. The black youth unemployment rate reached the lowest ever again in the history of our country. And (B3.6B) last year, Black and Hispanic American poverty reached the lowest ever in the history of our country. It's all building back up so quickly. And if you look at what we've done with criminal justice reform, if you look at what we've done with historically black colleges and universities, where we funded them, they couldn't get funded. Nobody was funding that for years and years and decades, nobody was funding them.

Vocabulary battles about Hispanic Community in B3.6A and B3.6B. First, B3.6A, explaining that Trump has suppressed the lowest Hispanic unemployment rate in American history. Second, last year, B3.6B, explaining that In 2019, Black and Hispanic Americans saw the lowest level of poverty in American history. Trump's goal is to make a battle for Hispanic Americans can discourse so that the public, especially Hispanic Americans, choose Trump in the presidential election. 


\subsection{Vocabulary For Marginalization}

The vocabulary is seen not as something neutral, but carries certain ideological implications. The words, sentences, structures, certain sentence forms, and propositions are not seen merely as a technical matter of grammar or linguistics, but an expression of ideology: an effort to form public opinion, affirm, and justify one's own party and exclude others. Language is not neutral because it carries certain ideological implications. The text produces a reading position for the audience, in the sense of providing perspective on how a text should be read and understood, even though the meaning of a text involves a transactional relationship with the reader. President Donald Trump's remarks at his first public event since being diagnosed with Covid-19. Trump marginalized certain parties which will be explained as follows:

\subsubsection{Vocabulary To Represent Joe Biden's} Marginalization

Vocabulary to express Joe Biden's marginalization in President Donald Trump's address at the first public event following the diagnosis of Covid-19 discovered 4 data, one of which will be presented below:

(B4.1)

Every day, more Black and Latino Americans are leaving behind left wing politicians and their failed ideology. It's what they are. They failed for many years and many, many decades. Democrats have run nearly every inner city in America and $I$ mean, for 100 years and their policies have delivered nothing but calamity, poverty and trouble.(B4.1A) Sleepy Joe Biden has betrayed Black and Latino Americans. If you think he can run this country, you're wrong. For half a century, shipping your jobs to China, that's what they've been doing. We're bringing the jobs back. We've been bringing them back. We've been charging China a lot of money too, with the tariffs, a lot of money, billions and billions of dollars.

Marginalization vocabulary of Joe Biden in datum B4.1 is B4.1A. By using this vocabulary, Trump made it clear that Biden had betrayed Black and Latino Americans because the Democratic official, Biden of the Democratic Party, sent the work of Black and Latino Americans to China. Trump wants to bring Black and Latino Americans jobs back to America. Trump's goal is to marginalize Biden so that society votes for Trump in the presidential election instead of voting for Biden.

\subsubsection{Vocabulary To Represent Obama's Marginalization}

Vocabulary to depict Obama's marginalization in President Donald Trump's address at the first public event following the diagnosis of Covid-19 discovered two data points, one of which will be explored below: (B4.5)
We're going to build up a peaceful and safer neighborhood program like you haven't seen with the highest standards of policing, we'll create a healthcare system that delivers better care at a lower cost. Obamacare is a disaster. We want to terminate it. We want to get great healthcare. And that's what we're doing. Great healthcare. And we'll always take care of pre-existing conditions, always. And I think we're at a point where we're getting and right now if you look at what we've done in healthcare, people don't talk about it. We've done an incredible job. Less expensive healthcare. Much better healthcare at a much less expensive price.

Obama's marginalization in datum B4.5 through the vocabulary Obamacare is a disaster. Through the use of this vocabulary, Trump explained that Obamacare was a disaster for American society. Obamacare or Affordable Care Act (ACA) at the beginning of its emergence. Obamacare is considered negative because of the high cost of protection for Americans. Therefore, Obamacare received a lot of criticism from the public.

Trump wants to change the healthcare system for the better and more affordable for Americans. Trump's goal to marginalize Obama is to expose the shortcomings that Obama has done. Considering Obama is a Democrat. The Democratic Party is a political opponent with Trump who belongs to the Republican Party. Therefore, Trump invites the American people to vote for Donald Trump in the upcoming presidential election.

\subsubsection{Vocabulary To Represent Donald Trump's Marginalization}

Vocabulary to reflect Donald Trump's marginalization in President Donald Trump's address at the first public event since his Covid-19 diagnosis discovered 6 data, one of which is as follows:

(B4.9)

(B4.9A) We're going to build up a peaceful and safer neighborhood program like you haven't seen with the highest standards of policing, $(B 4.9 B)$ we'll create a healthcare system that delivers better care at a lower cost. Obamacare is a disaster. (B4.9C) We want to terminate it. (B4.9D) We want to get great healthcare. And that's what we're doing. Great healthcare. And (B4.9E) we'll always take care of pre-existing conditions, always. And I think (B4.9F) we're at a point where we're getting and right now if you look at what we've done in healthcare, people don't talk about it. (B4.9G) We've done an incredible job. Less expensive healthcare.

Discussion of the marginalization of Donald Trump on datum B4.9 through the vocabulary $\mathrm{B} 4.9 \mathrm{~A}, \mathrm{~B} 4.9 \mathrm{~B}, \mathrm{~B} 4.9 \mathrm{C}, \mathrm{B} 4.9 \mathrm{D}, \mathrm{B} 4.9 \mathrm{~F}$, and B4.9G. Through the use of this vocabulary, Trump wants to show himself that the health system created by Trump wants to change the Obamacare health system from bad to better and more affordable for Americans. The purpose of marginalizing Trump is 
Trump wants to tell the advantages of the health system that Trump will make, so that Trump hopes the American people will vote for Trump in the presidential election.

To ease the discussion of the research findings, the table below shows the language selection technique in President Donald Trump's address at the first public event since his Covid-19 diagnosis:

Table 1. Vocabulary selection strategy in President Donald Trump's speech

\begin{tabular}{|c|c|c|c|c|}
\hline No & $\begin{array}{c}\text { Vocabulary } \\
\text { strategy }\end{array}$ & Type & Data & $\begin{array}{l}\text { Total } \\
\text { data }\end{array}$ \\
\hline \multirow[t]{3}{*}{1} & \multirow{3}{*}{$\begin{array}{l}\text { Vocabulary } \\
\text { for } \\
\text { classifying }\end{array}$} & $\begin{array}{l}\text { 1. Hope and } \\
\text { Planning }\end{array}$ & 2 & \multirow[t]{3}{*}{4} \\
\hline & & $\begin{array}{l}\text { 2. Achievement } \\
\text { and Concern }\end{array}$ & 1 & \\
\hline & & $\begin{array}{ll}\text { 3. } & \text { Belief and } \\
\text { Spirit }\end{array}$ & 1 & \\
\hline \multirow[t]{4}{*}{2} & \multirow{4}{*}{$\begin{array}{l}\text { Vocabulary } \\
\text { for limiting } \\
\text { views }\end{array}$} & $\begin{array}{l}\text { 1. Presidential } \\
\text { Election }\end{array}$ & 2 & \multirow[t]{4}{*}{7} \\
\hline & & 2. Economy & 2 & \\
\hline & & 3. $\quad$ Peace & 2 & \\
\hline & & 4. Health & 1 & \\
\hline \multirow[t]{3}{*}{3} & \multirow{3}{*}{$\begin{array}{l}\text { Vocabulary } \\
\text { for } \\
\text { discourse } \\
\text { battle }\end{array}$} & 1. Covid-19 & 1 & \multirow[t]{3}{*}{6} \\
\hline & & $\begin{array}{l}\text { 2. Black and } \\
\text { Latino } \\
\text { American }\end{array}$ & 3 & \\
\hline & & $\begin{array}{ll}\text { 3. } & \text { Hispanic } \\
\text { Community }\end{array}$ & 2 & \\
\hline \multirow[t]{3}{*}{4} & \multirow{3}{*}{$\begin{array}{l}\text { Vocabulary } \\
\text { for } \\
\text { marginalizat } \\
\text { ion }\end{array}$} & 1. Joe Biden & 4 & \multirow[t]{3}{*}{12} \\
\hline & & 2. Obama & 2 & \\
\hline & & $\begin{array}{ll}3 . & \text { Donal } \\
& \text { Trump } \\
\end{array}$ & 6 & \\
\hline
\end{tabular}

The researcher suggests that research on critical discourse analysis be developed by other prospective researchers. The researcher suggests that critical discourse analysis courses be taught in Postgraduate Linguistics. This study only provides the practice of critical discourse analysis from Fowler on speech discourse. There are many scopes of analysis that have not been discussed such as pronouns, language styles, speech rotation, modality, cohesion (unity), coherence (cohesion), sequencing, implicatures, and speech acts. There are many objects that can be analyzed by critical discourse analysis such as news, articles, opinions, short stories, novels, and others. Critical discourse analysis studies can help audiences to seek information from various sources so as not to be trapped in narrow and non-neutral thoughts conveyed by certain parties.

\section{CONCLUSIONS}

Trump's speech frame can be represented through vocabulary. Language classification system through four vocabulary selection strategies, namely classification, limiting views, discourse battle, and marginalization. Vocabulary can describe how the reality of the world is seen, giving a person the possibility to control and to regulate the experience of social reality.

From the result of data analysis, it can be found that there are 3 types of vocabulary for classifying, 4 types of vocabulary for limiting views, 3 types of vocabulary for discourse battle, and 3 types of vocabulary for marginalization. There are 3 types of vocabulary for classifying, namely hope and planning (2 data); achievements and worry (1 datum); and faith and spirit ( 1 datum). There are 4 types of vocabulary for limiting views, namely presidential election ( 2 data), economy (2 data), peace ( 2 data), and health ( 1 datum). There are 3 types of vocabulary for discourse battle, namely Covid19 (1 datum), Black and Latino American (3 data), Hispanic Community (2 data). There are 3 types of vocabulary for limiting views, namely Joe Biden (4 data), Obama (2 data), Donal Trump (6 data).

According to the findings of the study, Donald Trump wishes to project an image of himself as a context leader through the phrase selection method he employs in his speech. Donald Trump wishes to encourage the American people to vote for him as the country's next president. Therefore, Trump gave promises to increase health, economic, law, peace for Americans.

\section{ACKNOWLEDGMENTS}

This paper was fully supported by Education, Culture, Research, and Technology of Republic Indonesia and English Literary Program, Language and Letters Faculty, Surakarta University.

\section{REFERENCES}

[1] F. Baryam, "Ideology and Political Discourse: a Critical Discourse Analysis of Erdogan'S Political Speech," Arecls, vol. 7, no. January 2009, pp. 23-40, 2010, [Online]. Available: http://research.ncl.ac.uk/ARECLS/volume7/bayr am_vol7.pdf.

[2] J. H. Park, "Discourse construction of InterKorean summits in South Korean newspapers: A diachronic study," Lang. Commun., vol. 78, pp. 19-34, May 2021, doi: 10.1016/j.langcom.2021.02.001.

[3] E. Tarnarutckaia and A. Ensslin, "The myth of the 'clarté française': Language ideologies and metalinguistic discourse of videogame speech accents on Reddit," Discourse, Context Media, vol. 33, p. 100352, Mar. 2020, doi: 10.1016/j.dcm.2019.100352.

[4] V. Fromkin, R. Rodman, and N. Hyams, An Introduction to Language, 7th ed. Massachusetts: Michael Rosenberg, 2003.

[5] J. Jackson, "Language," Identity and Study Abroad, London: Equinox, 2008.

[6] A. Hidayah, "Frase Nomina Pelaku Endosentris Atributif Bahasa Inggris di Bidang Kantor Depan (Front Office) Hotel," Haluan Sastra Budaya, 
vol. 3, no. 2, pp. 105-117, 2019.

[7] C. Gu, "Forging a glorious past via the 'present perfect': A corpus-based CDA analysis of China's past accomplishments discourse mediat(is)ed at China's interpreted political press conferences," in Discourse, Context and Media, Aug. 2018, vol. 24, pp. 137-149, doi: 10.1016/j.dcm.2018.03.007.

[8] H. G. Widdowson and C. Kramsch, Oxford Introductions to Language Study-Series Editor: Language and Culture, no. March. Berkeley: California University, 2000.

[9] R. Jones, Discourse Analysis: A Resource Book For Students. Hong Kong: Academia, 2012.

[10] Y. A. Taha and R. Al-Khanji, "A Critical Discourse Analysis of Gaza Marches of Return Coverage in Selected Newspapers," Int. J. Linguist., vol. 12, no. 6, p. 163, 2020, doi: 10.5296/ijl.v12i6.17959.

[11] Y. Erdogan-Ozturk and H. Isik-Guler, "Discourses of exclusion on Twitter in the Turkish Context: \#ülkemdesuriyeliistemiyorum (\#idontwantsyriansinmycountry)," Discourse, Context Media, vol. 36, p. 100400, Aug. 2020, doi: 10.1016/j.dcm.2020.100400.

[12] A. K. Zenteno Jiménez and S. by Hilda Hidalgo Avilés, Introduction to Discourse Analysis, vol. 1, no. 2. 2013.

[13] T. A. Van Dijk, "Ideology and discourse analysis," J. Polit. Ideol., vol. 11, no. 2, pp. 115140, 2006, doi: 10.1080/13569310600687908.

[14] A. Bulan and K. Kasman, "Critical Discourse Analysis of Ahok's Speech in Kepulauan Seribu," Transform. J. Bahasa, Sastra, Dan Pengajarannya, vol. 2, no. 1, p. 50, 2018, doi: 10.31002/transformatika.v2i1.555.

[15] P. L. Dunmire, "Political Discourse Analysis: Exploring the Language of Politics and the Politics of Language," Linguist. Lang. Compass, vol. 6, no. 11, pp. 735-751, 2012, doi: 10.1002/lnc3.365.

[16] A. Leftwich, What is Politics? Cambridge: Polity Press Ltd, 2004.

[17] B. Adrian, The Language of Politics, vol. 2. New York: Routledge, 2000.

[18] J. Na, "Leo strauss political philosophy," Voprosy Filosofii, vol. 2019, no. 12. pp. 198203, 2019, doi: 10.31857/S004287440007537-5.

[19] T. A. Van Dijk, Society and discourse: How social contexts influence text and talk. Cambridge: Cambridge University Press, 2009.

[20] Eriyanto, Analisis Wacana: Pengantar Analisis Teks Media. Yogyakarta: LKiS Printing Cemerlang, 2011.

[21] A. Hidayah, "a Deixis Analysis of Song Lyrics in Back To You by Selena Gomez," Surakarta, vol. 2, no. 2, pp. 47-55, 2019.

[22] D. Liu and L. Lei, "The appeal to political sentiment: An analysis of Donald Trump's and Hillary Clinton's speech themes and discourse strategies in the 2016 US presidential election," Discourse, Context Media, vol. 25, pp. 143-152, Oct. 2018, doi: 10.1016/j.dcm.2018.05.001.

[23] L. J. Moleong, Metodologi Penelitan Kualitatif. Bandung: Remaja Rosdakarya, 2009.

[24] N. S. Sukmadinata, Metode Penelitian Pendidikan. Bandung: Remaja Rosdakarya, 2010.

[25] S. Arikunto, Prosedur Penelitian Suatu Pendekatan Praktik. Jakarta: Rineka Cipta, 2002.

[26] A. Siyoto, S., \& Sodik, Dasar Metodologi Penelitian. Yogyakarta: Literasi Media Publishing, 2015.

[27] S. Siyoto, Sandu \& Ali, Dasar Metodologi Penelitian. Yogyakarta: Literasi Media Publishing, 2015.

[28] A. Reyes, "Building intimacy through linguistic choices, text structure and voices in political discourse," Lang. Commun., vol. 43, pp. 58-71, Jul. 2015, doi: 10.1016/j.langcom.2015.05.002. 